\title{
Synthesis and characterization of $\mathrm{Pt}$ nanocatalyst on $\mathrm{Ru}_{0.7} \mathrm{Ti}_{0.3} \mathrm{O}_{2}$ support as a cathode for
}

\section{fuel cells application}

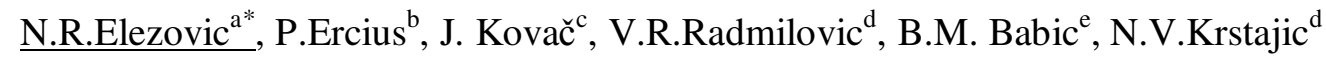 \\ ${ }^{a}$ Institute for Multidisciplinary Research, University of Belgrade, Kneza Viseslava 1, Belgrade, \\ Serbia, e-mail address: nelezovic@tmf.bg.ac.rs, ${ }^{b}$ National Center for Electron Microscopy, \\ LBNL University of California, Berkeley, USA, ${ }^{c}$ Jozef Stefan Institute, Jamova 39, SI-1000 \\ Ljubljana, Slovenia, ${ }^{d}$ Faculty of Technology and Metallurgy, University of Belgrade, \\ Karnegijeva 4, Belgrade, Serbia, ${ }^{e}$ Vinca Institute of Nuclear Sciences, University of Belgrade, \\ Belgrade, Serbia,
}

\section{Abstract}

Ruthenium oxide/titanium oxide, with a Ru:Ti atomic ratio of 7:3 was synthesized by modified sol-gel procedure and used as a support for platinum nanocatalyst for oxygen reduction reaction. The synthesized materials were characterized in terms of morphology, particle size distribution, chemical and phase composition by $\mathrm{X}$ ray diffraction (XRD), X-ray photoelectron spectroscopy (XPS), high angle annular dark filed scanning transmission electron microscopy (HAADF, STEM) and electron energy loss spectroscopy (EELS). XPS spectra revealed that $\mathrm{Ru}$ atoms were in mainly in $\mathrm{Ru}(4+)$ oxidation state, the $\mathrm{Ti}$ atoms in $\mathrm{Ti}(4+)$ oxidation state, whereas the Pt-atoms were in metallic state. TEM analysis proved that platinum nanoparticles nucleated at both oxide species and homogeneous distribution was observed. The average platinum nanoparticle size was $3.05 \mathrm{~nm}$.

Electrochemically active surface area of platinum was $32 \mathrm{~m}^{2} \mathrm{~g}^{-1}$. Kinetics of the oxygen reduction was studied at rotating disc electrode in $0.5 \mathrm{~mol} \mathrm{dm}^{-3} \mathrm{HClO}_{4}$ solution, at $25^{\circ} \mathrm{C}$. The catalytic activities expressed in terms of specific activity (per electrochemically active surface area of platinum) and mass activity (per mass of platinum) were determined and compared to Pt catalyst on carbon support. The high catalytic activity was proven by electrochemical characterization. 
Keywords: ruthenium oxide based support, titanium oxide support, Pt nanocatalyst, oxygen reduction reaction, acid solution.

*Corresponding author, ISE member

E-mail: nelezovic@tmf.bg.ac.rs

\section{Introduction}

Proton exchange membrane fuel cells (PEMFC) are considered as the promising environmentally friendly future power sources. However, before commercialization many challenges have to be resolved. It is widely accepted that platinum based catalysts exhibit the best catalytic activity for both anode and cathode reactions: the oxygen reduction and hydrogen oxidation [1-5]. In order to diminish amount of $\mathrm{Pt}$ and thus lower the system costs, $\mathrm{Pt}$ nanoparticles homogenously distributed over the proper carbon supporting materials are used [68]. The power loss at the cathode due to slow oxygen reduction kinetics is other limiting factor $[9,10]$. The overall performance of fuel cell is much more influenced by oxygen reduction, due to slow oxygen reduction kinetics and much higher overpotential, compared to faster hydrogen oxidation at Pt based catalysts. Namely, the thermodynamic reversible potential for oxygen reduction reaction on $\mathrm{Pt}$ is $1.23 \mathrm{~V}$ vs. reversible hydrogen electrode, until the open circuit potential established is about $0.3 \mathrm{~V}$ lower. This large potential loss was attributed to the fact that the surface of Pt was covered with oxygen containing species from water (e.g. $\mathrm{OH}$ ), or other adsorbed anions. Further improvement of fuel cell performance requires development of a more active catalyst for oxygen reduction.

The other important fact is the support material. Besides enabling high surface area for catalysts particles spreading, it should be highly conductive and stable in terms of chemical and corrosion stability. State of the art support materials for Pt catalysts are carbon based, commercially named Vulcan XC-72 and Ketjen black. However, these carbon based supports tend to corrode at the high anodic potentials achieved during start/stop fuel cell conditions. For 
this reason, catalyst degradation and shortened lifetime are major unsolved problems [11]. In the presence of water, carbon is consumed [12] through the following heterogeneous reaction:

$$
\mathrm{C}+\mathrm{H}_{2} \mathrm{O} \rightarrow \mathrm{H}_{2}+\mathrm{CO}
$$

This reaction is catalysed in the presence of platinum. Moreover, the reaction product $\mathrm{CO}$ was proven as the poison for Pt based catalyst.

The above mentioned disadvantages of carbon based supports have imposed the need for new supporting materials, to improve limited stability and durability of the catalysts. Metal oxide based supports were previously investigated as the promising materials for low temperature fuel cells applications $[13,14]$. According to the chlor-alkali industry investigations the $\mathrm{RuO}_{2}-\mathrm{TiO}_{2}$ system is used as dimensional stable anodes [15-17]. High electrical conductivity, structurally and chemically stability under conditions similar to those in PEM fuel cells, was proven. Good electrical conductivity and high electrochemical stability of ruthenium oxide within the hydrogen and oxygen evolution potentials region was referred [18]. Haas et al. investigated mixture of binary oxide ruthenium and titanium as a promising support for Pt based catalysts, for fuel cells application, in acid solution [19]. Pt catalyst on this support was synthesized by impregnationreduction method. Determined electrochemically active surface area of $\mathrm{Pt}$ was comparable to $\mathrm{Pt}$ on carbon support, at the same catalysts loading. However, the results for catalytic activity for oxygen reduction reaction were not presented [19]. Pt nanoparticles deposited by impregnation method on titanium-ruthenium dioxide based support, synthesized by wet chemical synthesis procedure, was tested as the catalyst for oxygen reduction [20]. The referred values for the mass and specific activities of oxygen reduction were $54 \mathrm{~mA} \mathrm{mg}{ }_{\mathrm{Pt}}^{-1}$ and $284 \mu \mathrm{A} \mathrm{cm}{ }_{\mathrm{Pt}}^{-2}$ [20]. Composite electrocatalysts composed of $\mathrm{RuO}_{2}$ nanosheets and carbon supported Pt exhibited a $25 \%$ higher mass activity toward oxygen reduction than the pristine $\mathrm{Pt} / \mathrm{C}$ electrocatalyst [21]. Moreover, $\mathrm{RuO}_{2}$ as a well known catalyst for oxygen evolution reaction (OER) mixed with ORR catalysts enhances the oxidation of water $/ \mathrm{OH}$ - to oxygen and therefore provide significant protection of other redox active species at high potentials. The loss of electrochemically active 
surface area (ECSA) and carbon support degradation, for ORR combined with OER catalyst were significantly reduced if compared to an unprotected catalyst layer [22].

In this manuscript $\mathrm{RuO}_{2}-\mathrm{TiO}_{2}$, with a $\mathrm{Ru}$ :Ti atomic ratio of 7:3, was synthesized by solgel procedure and used as the support for Pt nanocatalyst. The oxygen reduction reaction in 0.5 mol dm ${ }^{-3} \mathrm{HClO}_{4}$ was studied at synthesized catalyst. The aim of this work is to reveal influence of $\mathrm{RuO}_{2}-\mathrm{TiO}_{2}$ support on the catalytic activity for oxygen reduction. Carbon supported $\mathrm{Pt}$ catalyst on commercial Vulcan XC 72 support was used for comparison of the catalytic activities.

\section{Experimental}

\subsection{Preparation of $\mathrm{Ru}_{0.7} \mathrm{Ti}_{0.3} \mathrm{O}_{2}$ support}

$\mathrm{RuO}_{2}-\mathrm{TiO}_{2}$ powder was synthesized through a modified sol-gel route procedure proposed by Boujday et.al. [23]. A procedure implies acid-catalyzed sol-gel method in a nonaqueous medium. Sols were prepared by adding a volume of $0.9 \mathrm{ml}$ of $37 \%$ solution of hydrochloric acid to a $40 \mathrm{ml}$ of $97 \%$ solution of titanium (IV)isopropoxide, Ti[OCH(CH3)2]4, (Alfa Aesar, Germany), and an appropriate amount of RuCl3 (Merck, Germany), previously dissolved in $10 \mathrm{ml}$ of water, under vigorous steering. Mixture was placed in glass tubes, sealed and placed 5 days at room temperature. In the presence of such amount of hydrochloric acid, the hydrolysis proceeded without forming a precipitate, leading to a transparent sol. Gellification of the sol was achieved by adding an appropriate amount of water.

The sample was dried by freeze - drying method using Modulyo Freeze Dryer System Edwards, England, consisting of freeze dryer unit at High Vacuum Pump E 2 M 8 Edwards. Samples was pre-frozen in deep-freeze refrigerator at $-30^{\circ} \mathrm{C}$ for 24 hours. After that, sample was frozen drying in the acrylic chamber with shelves arrangements mounted directly on the top of the condenser of Freeze Dryer. The vacuum during twenty hours of freeze - drying was around 4 mbar. 
Dried sample was heated to obtain anatase crystallized phase and to remove traces of organics in a conventional furnace, at $400^{\circ} \mathrm{C}$, for 2 hours. After the treatment, the furnace was cooled at room temperature.

\subsection{Preparation of $\mathrm{Ru}_{0.7} \mathrm{Ti}_{0.3} \mathrm{O}_{2}$ supported Pt catalysts}

Pt (20 wt.\%) catalyst on $\mathrm{Ru}$ doped $\mathrm{TiO}_{2}$ support was prepared by borohydride reduction method [24]. The main steps of this synthesis were following: appropriate amount of $\mathrm{H}_{2} \mathrm{PtCl}_{6}$ was dissolved in D.I. water. $\mathrm{Ru} / \mathrm{TiO}_{2}$ powder was dispersed in D.I. water and then mixed by adding platinum salt solution under constant stirring. The mixture of platinum salt and support was reduced by excess of sodium borohydride solution. Prepared precipitate was washed with water $(18 \mathrm{M} \Omega)$ and then dried at $80{ }^{\circ} \mathrm{C}$.

The Vulcan/Pt catalyst, with specific surface area of $92 \mathrm{~m}^{2} \mathrm{~g}^{-1}$, used as benchmark, was synthesized by modified ethylene glycol method on a commercial VulcanXC-72 support. The synthesis procedure was described in Ref. 25.

\subsection{Physical-chemical characterization of the support and catalyst}

The support powder was characterized by the X-ray diffraction (XRD) technique on a Siemens D500 X-ray diffractometer using $\mathrm{Cu} \mathrm{K} \alpha$ radiation with a Ni filter. The $2 \theta$ angular regions between $5^{\circ}$ and $80^{\circ}$ were explored at a scan rate of $0.02^{\circ} / \mathrm{s}$ with the angular resolution of $0.02^{\circ}$ for all XRD tests.

The X-ray photoelectron spectroscopy (XPS) analyses were carried out on the PHI-TFA XPS spectrometer produced by Physical Electronics Inc. Sample powders were deposited on vacuum compatible carbon adhesive tape and introduced in ultra-high vacuum spectrometer. The analyzed area was $0.4 \mathrm{~mm}$ in diameter and the analyzed depth was about $3-5 \mathrm{~nm}$. This high surface sensitivity is a general characteristic of the XPS method. Sample surfaces were excited by X-ray radiation from monochromatic Al source at photon energy of $1486.6 \mathrm{eV}$. The highenergy resolution spectra were acquired with energy analyzer operating at resolution of about 0.6 $\mathrm{eV}$ and pass energy of $29 \mathrm{eV}$. During data processing the spectra from the surface were aligned 
by setting the $\mathrm{C} 1 \mathrm{~s}$ peak at $284.4 \mathrm{eV}$, characteristic for $\mathrm{C}-\mathrm{C}$ bonds. The accuracy of binding energies was about $\pm 0.4 \mathrm{eV}$. XPS measurements were performed on three different places of the sample and all were very reproducible.

Transmission electron microscopy (TEM) sample preparation included sonication of $\mathrm{Pt}$ $\mathrm{Ru}_{0.7} \mathrm{Ti}_{0.3} \mathrm{O}_{2}$ catalyst suspensions in ethanol for 5 minutes. After sonication, these suspensions were dropped on glassy carbon grids and dried in air. The samples were characterized for morphology, particle size distribution and chemical composition by multiple methods: conventional TEM (CTEM), high angle annular dark scanning transmission electron microscopy (HAADF, STEM), electron energy loss spectroscopy (EELS) and energy dispersive spectroscopy (EDX) technique. HAADF-STEM imaging and EELS were collected on the aberration corrected TEAM0.5 and TEAM I STEMs operated at $80 \mathrm{kV}$ and 300kV. HAADFSTEM was chosen because of its strong correlation between atomic number and image intensity which can distinguish between heavy elements such as Pt and the light support components such as $\mathrm{Ru}$ or Ti oxide species. The average value the major and minor axes of the particles were used to calculate the average particle diameters in order to take into account their non-spherical shape. Energy dispersive spectroscopy (EDS) spectra from single points and 2D maps were collected on the Titan-X TEM operated at $200 \mathrm{kV}$ in the STEM mode using $\sim 1 \mathrm{~nm}$ beam diameter. High resolution phase contrast imaging (HREM) was performed by the TEAM0.5 and TEAM I aberration corrected TEMs. Crystallographic information from individual Pt particles, such as the presence of facets, equilibrium shape, etc., was obtained by numerical Fourier filtering (FFT, Fast Fourier Transformation) of the digital image power spectra. All TEM characterization was done at the National Center for Electron Microscopy, Lawrence Berkeley National Laboratory.

\subsection{Electrochemical characterization}

Electrochemical measurements were performed in a conventional three-compartment glass cell, at the temperature of $25^{\circ} \mathrm{C}$, in $0.5 \mathrm{~mol} \mathrm{dm}^{-3} \mathrm{HClO}_{4}$ high-purity solution (Spectrograde, Merck), prepared in $18.2 \mathrm{M} \Omega$ pure water. The counter electrode was a platinum sheet of $5 \mathrm{~cm}^{2}$ 
geometric area. A platinum plated Pt reversible hydrogen electrode (RHE) in the same solution and at the same temperature was used as the reference electrode.

The working electrode was gold rotating disk (diameter $5 \mathrm{~mm}$ ). The ink was suspension of catalyst in ethanol and Nafion solution (5 wt.\% Aldrich solution). It was first ultrasonically dispersed for $30 \mathrm{~min}$. Aliquot of ink was transferred on the gold electrode and dried at $80^{\circ} \mathrm{C}$ for 10 min to obtain thin film. The Pt loading was $8 \mu \mathrm{g}$ of Pt. Mayrhofer et al. [10] suggested importance of optimal loading for the fuel cell cathode rotating disc electrode (RDE) measurements. Namely, due to low Pt loading RDE could not be completely and homogenously covered, so the geometric surface area could not be well defined. On the contrary, too high Pt loading implies that mass transport conditions necessary for the RDE investigations are no longer satisfied.

Electrochemical measurements have been performed using potentiostat/galvanostat PAR Model 273. The cyclic voltammetry was performed in the potential range from $0.03 \mathrm{~V}$ to $1.2 \mathrm{~V}$ vs RHE, in $0.5 \mathrm{~mol} \mathrm{dm}^{-3} \mathrm{HClO}_{4}$ solution at the sweep rate of $100 \mathrm{mV} \mathrm{s}^{-1}$. In order to obtain stable, reproducible results, the repetitive cycling, at least 20 cycles was performed, prior the recording of the corresponding cyclic voltammogram. The oxygen reduction reaction was studied by linear sweep voltammetry (positive going sweeps) at rotating gold disc electrode applying sweep rate of $20 \mathrm{mV} \mathrm{s}^{-1}$.

\section{Results and discussion}

\subsection{Physicochemical characterization}

The phase composition of $\mathrm{Ru}_{0.7} \mathrm{Ti}_{0.3} \mathrm{O}_{2}$ support was determined by X-ray diffraction analysis. Typical XRD pattern is presented in Figure 1.

The presence of $\mathrm{RuO}_{2}$ and $\mathrm{TiO}_{2}$ peaks is observed. Observed peaks belong to anatase ( $2 \theta$ $=25.28^{\circ}, 37.80^{\circ}, 48.05^{\circ}$ and $\left.53.89^{\circ}\right)$, or rutile $\left(2 \theta=27^{\circ}\right.$ and $\left.36^{\circ}\right) \mathrm{TiO}_{2}$ phase. All these peaks are in good accordance with the standard spectrum JCPDS No 88-1175 and 84-1286 [26]. $\mathrm{RuO}_{2}$ 
peaks of crystallographic orientation (110), (101), (200) and (211) are presented, including almost all the $\mathrm{RuO}_{2}$ phases between $2 \theta=25$ and $65^{\circ}$, according to JCPDS pattern (No. 88-0322).

Figure 2 shows the XPS survey spectrum from the $\mathrm{Pt} / \mathrm{Ru}_{0.7} \mathrm{Ti}_{0.3} \mathrm{O}_{2}$ sample. From this spectrum elements $\mathrm{Ti}, \mathrm{Ru}, \mathrm{Pt}, \mathrm{O}$ and $\mathrm{C}$ were proved to be present on the surface [27].

Figure 3a shows the $\mathrm{Pt} 4 \mathrm{f}$ spectrum. The main $\mathrm{Pt} 4 \mathrm{f} 7 / 2$ peak is at $71.1 \mathrm{eV}$ and it is assigned to $\operatorname{Pt}(0)$ metallic state.

Figure $3 \mathrm{~b}$ shows the Ti $2 \mathrm{p}$ spectrum. The Ti $2 \mathrm{p} 3 / 2$ peak is at $458.4 \mathrm{eV}$ and it is assigned to $\mathrm{Ti}(4+)$ in $\mathrm{TiO} 2-$ like chemical environment. Also the $\mathrm{Ru} 3 \mathrm{p} 3 / 2$ peaks are present in this energy range. The $\mathrm{Ru} 3 \mathrm{~d}$ spectrum is given in Figure 3c. By deconvolution we found two types of $\mathrm{Ru}$ doublets. In the first one the $\mathrm{Ru} 3 \mathrm{~d} 5 / 2$ peak is at $280.8 \mathrm{eV}$ and it probably corresponds to $\mathrm{Ru}(2+)$, whereas the second doublet is at $281.9 \mathrm{eV}$ corresponding to $\mathrm{Ru}(4+)$ in $\mathrm{RuO}_{2}$-like ambient. $\mathrm{Ru}$ spectrum strongly interferes with carbon C 1s spectrum which has two peaks in this region: $\mathrm{C} 1 \mathrm{~s}$ at $284.4 \mathrm{eV}$ related to $\mathrm{C}-\mathrm{C} / \mathrm{C}-\mathrm{H}$ bonds and $\mathrm{C} 1 \mathrm{~s}$ peak at $287.6 \mathrm{eV}$ related with $\mathrm{C}-\mathrm{O}, \mathrm{C}=\mathrm{O}$ bonds.

Figure 3d shows O 1s spectrum deconvoluted in three peaks at $529.5 \mathrm{eV}$ and $530.9 \mathrm{eV}$, both related with metallic oxides $\left(\mathrm{O}(2-)\right.$ in $\mathrm{TiO}_{2}$ and $\left.\mathrm{RuO}_{2}\right)$ and peak at $533.0 \mathrm{eV}$ related with $\mathrm{OH}, \mathrm{H}_{2} \mathrm{O}$ and/or $\mathrm{C}-\mathrm{O}$ bonds. It should be emphasized that no contaminants were detected by XPS measurements.

The morphology, chemical composition and particle size distribution were studied by HAADF-STEM and EELS. Typical overall platinum particle distribution onto the support is presented in Figure 4a, while the histogram of Pt particle size distribution is shown in Fig.4b.

A single mode normal particle size distribution was observed. The average Pt particle size obtained by the HAADF-STEM technique was $3.05 \mathrm{~nm}$. HAADF technique was chosen because of correlation between atomic number and intensity of the image. It provides possibility to distinguish heavy elements such as Pt (white area in Fig.4a) and easier elements of the support. 
The distribution of $\mathrm{RuO}_{2}$ and $\mathrm{TiO}_{2}$ species in a relatively thin specimen region, measured by EDX mapping is presented in Figure.5. Oxygen distribution is not shown for clarity.

Electron energy loss spectroscopy results also confirmed the presence $\mathrm{TiO}_{2}$, as well as $\mathrm{RuO}_{2}$ in the catalyst support (Fig.6a and Fig.6b). Energy loss edges for Ti, $\mathrm{L}_{3}$ at $456 \mathrm{eV}$ and $\mathrm{L}_{2}$ at $462 \mathrm{eV}$, and $\mathrm{O} \mathrm{K}$ edge at $532 \mathrm{eV}$, obtained from the marked white circle region (Fig.6a), confirm the presence of $\mathrm{TiO}_{2}$ in the substrate. EELS spectra taken from white square region (Fig.6b) indicates the presence of a small amount of $\mathrm{RuO}_{2}$ in a $\mathrm{TiO}_{2}$ grain.

Nucleation of Pt particles is always associated with $\mathrm{RuO}_{2}$ or $\mathrm{TiO}_{2}$ particle substrate, as indicated in HREM images, shown in Figure 7a and 7b. Is can be seen that Pt particles (110) nucleated at $\mathrm{RuO}_{2}(012)$ crystallographic orientation, as well as at $\mathrm{TiO}_{2}(110)$.

\subsection{Electrochemical characterization of Pt catalyst on $\mathrm{Ru}_{0.7} \mathrm{Ti}_{0.3} \mathrm{O}_{2}$ support}

Cyclic voltammogram at $\mathrm{Pt} / \mathrm{Ru}_{0.7} \mathrm{Ti}_{0.3} \mathrm{O}_{2}$, recorded in the potential range from $0.03 \mathrm{~V}$ to $1.2 \mathrm{~V}$ vs RHE, in $0.5 \mathrm{~mol} \mathrm{dm}{ }^{-3} \mathrm{HClO}_{4}$ solution at the sweep rate of $100 \mathrm{mV} \mathrm{s}^{-1}$ is presented in Figure 8. Typical platinum voltammogram shape in acid solutions, with well pronounced regions of underpotential deposition of hydrogen and oxidation/reduction of oxygen containing species were observed. Electrochemically active surface area was determined by integration of anodic part of cyclic voltammetry curve in the potential region of under potential deposition of hydrogen, assuming the value of $210 \mu \mathrm{C} \mathrm{cm}^{-2}$ for the full monolayer [28]. The obtained value was $32 \mathrm{~m}^{2} \mathrm{~g}^{-1}$.

The oxygen reduction reaction was studied by linear sweep voltammetry (positive going sweep) at rotating gold disc electrode. Polarization curves obtained in $0.5 \mathrm{~mol} \mathrm{dm}{ }^{-3} \mathrm{HClO}_{4}$ at different rotation rates, applying sweep rate of $20 \mathrm{mV} \mathrm{s}^{-1}$, are presented in Figure 9. The presented current densities are normalized to the geometric surface electrode area. 
As it is well known oxygen reduction takes place under mixed control (diffusion of oxygen trough the solution and charge transfer reaction), the measured current density at the constant potential value can be presented as the sum of reciprocals, as follows:

$$
\frac{1}{j}=\frac{1}{j_{k}}+\frac{1}{j_{L}}
$$

In this well known Koutecky-Levich equation $j_{k}$ is kinetic current density and $j_{L}=B \omega^{-1 / 2}$ is diffusion limiting current density, which is the linear function of square root of the rotation rate $-\omega, \mathrm{B}=0.62 n F D_{O_{2}}^{2 / 3} v^{-1 / 6} C_{0}$, where $\mathrm{n}$ is number of electrons exchanged, $\mathrm{F}$ Faraday constant, $v$ - kinematic viscosity of the solution and $D_{O_{2}}$ and $C_{0}$ are diffusion coefficient and concentration of dissolved oxygen, respectively.

Kinetic current densities at each potential were determined by applying equation (2). Levich-Koutecky dependences at different potential values were presented in Figure 10.

Linearity and parallelism of obtained dependences can be noticed, indicating first order kinetics per molecular oxygen.

In order to make proper comparison of the catalytic activities for oxygen reduction Tafel plots in terms of potential - logarithm of kinetic current density are presented in Fig.11.

Two different Tafel slopes were obtained: one close to $60 \mathrm{mV} \mathrm{dec}^{-1}$ in low current densities region and other $\sim 120 \mathrm{mV} \mathrm{dec}^{-1}$, in high current densities region, as it was already referred for Pt based catalysts in acid solutions. Damjanovic and co-workers [29, 30] interpreted the high Tafel slope value as the consequence of low oxygen species coverage, independent on potential, leading to Langmuirian adsorption conditions, while the lower slope was ascribed to Temkin adsorption and potential-dependent coverage of oxygen species. For both current density regions the first electron transfer was proposed as rate determining step. This explanation for ORR mechanism at Pt has been proposed for both alkaline and acid solutions.

The comparison of the catalytic activities between $\mathrm{Pt} / \mathrm{Ru}_{0.7} \mathrm{Ti}_{0.3} \mathrm{O}_{2}$ catalyst and carbon supported one was done in terms of specific activity, per real electrochemically active surface 
area of Pt, and mass activity, per mass of Pt loaded. The results are presented in Table1, at the constant potential values of $0.85 \mathrm{~V}$ and $0.90 \mathrm{~V}$ vs RHE, as it is common and widely accepted approach for oxygen reduction reaction at Pt based catalysts in acid solutions. The results related to $\mathrm{Pt} / \mathrm{C}$ benchmark catalyst's activity assessment were already published [31]. The synthesized $\mathrm{Pt} / \mathrm{Ru}_{0.7} \mathrm{Ti}_{0.3} \mathrm{O}_{2}$ catalyst expressed high catalytic activity, specific activity higher than carbon supported, while mass activities were similar.

Table1. Comparison of the specific and mass activities of $\mathrm{Pt} / \mathrm{Ru}_{0.7} \mathrm{Ti}_{0.3} \mathrm{O}_{2}$ and $\mathrm{Pt} / \mathrm{C}$ catalysts, at the constant potential

The main role of ruthenium oxide in the support was to provide its conductivity and stability as it was already discussed in introduction part. It is well known that $\mathrm{TiO}_{2}$ is characterized by excellent chemical and corrosion stability in both acid and alkaline environment. As it belongs to semi conductive materials conductivity has to be improved. On the other hand, Ru based catalysts were considered as the catalysts for oxygen reduction reaction, too [32-35]. However, Ru based catalysts exhibited much lower catalytic activities if compared to Pt based. The oxygen reduction at $\mathrm{Ru}$-based catalysts does not take place in the same potential range like at Pt based catalysts. Namely, it is common to compare catalytic activities for oxygen reduction reaction between $\mathrm{Pt}$ based catalysts at 0.85 or $0.90 \mathrm{~V}$ vs RHE, where the same reaction at $\mathrm{Ru}$ based catalysts does not take place at all. It is well known that open circuit potential for oxygen reduction at $\mathrm{Ru}$ based catalysts is from $0.80 \mathrm{~V}$ to $0.85 \mathrm{~V}$ vs $\mathrm{RHE}$. Therefore, the $\mathrm{Ru}$ contribution to the $\mathrm{Pt}$ catalyst activity for oxygen reduction reaction in the potential range from $0.85 \mathrm{~V}$ to $0.90 \mathrm{~V}$ vs RHE [32-35], can be neglected.

Increased catalytic activity of the $\mathrm{Pt} / \mathrm{Ru}_{0.7} \mathrm{Ti}_{0.3} \mathrm{O}_{2}$ catalyst could be explained by effect of the support on the electronic structure of the catalyst due to the so called Strong Catalyst Support Interaction (SCSI) [36, 37]. Ruthenium oxide can be considered as interactive support, so the contribution to the electrochemical reaction is possible. It is well known that oxide with $\mathrm{RuO}_{2}$ used as catalyst support could transport protons, in a way that is not possible for carbon based 
materials $[15,38]$. However, in this specific case the contribution to the electrochemical oxygen reduction is not possible in the potential range of practical interest for Pt based catalyst in acid solutions ( $0.85 \mathrm{~V}$ to $0.90 \mathrm{~V}$ vs RHE), due to difference in the potential ranges where the oxygen reduction takes place at $\mathrm{Pt}$ and $\mathrm{Ru}$ catalysts [32-35].

Titanium oxide is considered as very stable in acid and alkaline environments. $\mathrm{RuO}_{2}$ as a well known catalyst for oxygen evolution reaction (OER) if present in ORR catalysts enhances the oxidation of water/OH- to oxygen and therefore provide significant protection of other redox active species at high potentials, as it was referred by Srivastava et al. [22].

\section{Conclusion}

Pt catalyst on $\mathrm{Ru}_{0.7} \mathrm{Ti}_{0.3} \mathrm{O}_{2}$ was synthesized and characterized as the catalysts for oxygen reduction reaction in acid solution. The support was synthesized by sol-gel procedure, while platinum nanoparticles were deposited onto it by borohydride reduction method. XRD, XPS, HRTEM and EELS analysis of the supporting materials confirmed presence both oxide species ruthenium oxide, crystallographic orientation (012) and titanium oxide, orientation (110). Platinum nanoparticles nucleated at both oxide species and homogeneous distribution was observed. The average Pt particle size was $3.05 \mathrm{~nm}$. Electrochemically active surface area of Pt, determined by cyclic voltammetry was $32 \mathrm{~m}^{2} \mathrm{~g}^{-1}$. High catalytic activity for oxygen reduction of the synthesized catalyst was confirmed, in terms of specific and mass activity, at the potential values of $0.85 \mathrm{~V}$ and $0.90 \mathrm{~V}$ vs RHE. It can be concluded that Pt supported on $\mathrm{Ru}_{0.7} \mathrm{Ti}_{0.3} \mathrm{O}_{2}$ is promising catalysts for low temperature fuel cells application.

\section{Acknowledgement}

This work was financially supported by Ministry of Education, Science and Technological Development Republic of Serbia, under contract No 172054. We acknowledge the support for XPS measurements from Jozef Stefan Institute, Ljubljana, Slovenia, under bilateral collaboration project No 451-03-3095/2014-09/26. Electron microscopy characterization was performed at the National Center for Electron Microscopy, Lawrence Berkeley National 
Laboratory, which is supported by the Office of Science, Office of Basic Energy Sciences, of the U.S. Department of Energy under Contract No. DE-AC02-05CH11231. V. R. Radmilovic acknowledges supports from the Serbian Academy of Sciences and Arts. 


\section{Figure captions}

Fig.1. XRD diffraction patterns of $\mathrm{Ru}_{0.7} \mathrm{Ti}_{0.3} \mathrm{O}_{2}$ support.

Fig.2. XPS survey spectrum acquired on the $\mathrm{Pt} / \mathrm{Ru}_{0.7} \mathrm{Ti}_{0.3} \mathrm{O}_{2}$ sample.

Fig.3. XPS spectra Pt 4f (a), Ti 2p, Ru 3p (b), Ru 3d, C 1s (c) and O 1s (d) obtained on the Pt/ $\mathrm{Ru}_{0.7} \mathrm{Ti}_{0.3} \mathrm{O}_{2}$ surface.

Fig.4: a) HAADF-STEM image of Pt particles distribution on $\mathrm{Ru}_{0.7} \mathrm{Ti}_{0.3} \mathrm{O}_{2}$ support; b) histogram of Pt particle size distribution.

Fig.5. Distribution of $\mathrm{RuO}_{2}$ and $\mathrm{TiO}_{2}$ measured by EDX mapping, in $\mathrm{Ru}_{0.7} \mathrm{Ti}_{0.3} \mathrm{O}_{2}$ support.

Fig.6a. Energy loss edges for Ti, L3 at $456 \mathrm{eV}$ and L2 at $462 \mathrm{eV}$, and $\mathrm{O} \mathrm{K}$ edge at $532 \mathrm{eV}$, obtained from the white circle region, showing $\mathrm{TiO}_{2}$ substrate.

Fig.6b. EELS spectra taken from white square region: indication of the presence of small amount of $\mathrm{RuO}_{2}$ in $\mathrm{TiO}_{2}$ grain.

Fig.7. HREM images showing nucleation of $\mathrm{Pt}$ particles on $\mathrm{RuO}_{2}$ (a) or $\mathrm{TiO}_{2}$ (b) particle in $\mathrm{Pt} / \mathrm{Ru}_{0.7} \mathrm{Ti}_{0.3} \mathrm{O}_{2}$ substrate.

Fig. 8. Cyclic voltammogram obtained at $\mathrm{Pt} / \mathrm{Ru}_{0.7} \mathrm{Ti}_{0.3} \mathrm{O}_{2}$ in $0.5 \mathrm{~mol} \mathrm{dm}{ }^{-3} \mathrm{HClO}_{4}$ at sweep rate of $100 \mathrm{mV} \mathrm{s}^{-1}$, at $25^{0} \mathrm{C}$.

Fig.9. Polarization curves for oxygen reduction reaction at $\mathrm{Pt} / \mathrm{Ru}_{0.7} \mathrm{Ti}_{0.3} \mathrm{O}_{2}$ in $0.5 \mathrm{~mol} \mathrm{dm}{ }^{-3} \mathrm{HClO}_{4}$ at sweep rate of $20 \mathrm{mV} \mathrm{s}^{-1}$, at $25^{\circ} \mathrm{C}$. Currents densities are presented per geometric surface area of the RDE.

Fig.10. Lewich-Koutecky plots at different constant potentials for $\mathrm{Pt} / \mathrm{Ru}_{0.7} \mathrm{Ti}_{0.3} \mathrm{O}_{2}$ catalyst.

Fig.11. Tafel plots for oxygen reduction reaction at $\mathrm{Pt} / \mathrm{C}$ and $\mathrm{Pt} / \mathrm{Ru}_{0.7} \mathrm{Ti}_{0.3} \mathrm{O}_{2}$ catalyst, in $0.5 \mathrm{~mol}$ $\mathrm{dm}^{-3} \mathrm{HClO}_{4}$, at $25^{0} \mathrm{C}$. 


\section{References:}

[1] M.T.Peffet, J.G.Beery, S.Gottesfeld, J. Electrochem. Soc. 135 (1988) 1431-1436.

[2] T.Toda, H.Igarashi, H.Uchida, M.Watanabe, J. Electrochem. Soc. 146 (1999) 3750-3756.

[3] S. Zhang, Y. Shao, G. Yin, Y. Lin, Appl. Catal. B: Environ. 102 (2011) 372-377.

[4] T. Kottakkat, A. K. Sahu, S. D. Bhat, P. Sethuraman, S. Parthasarathi, Appl. Catal. B: Environ. 110 (2011)178-185.

[5] D. Sebastian, A. G. Ruiz, I. Suelves, R. Moliner, M. J. Lazaro, V. Baglio, A. Stassi, A. S. Arico, Appl. Catal. B: Environ. 115-116(2012)269-275.

[6] U. A. Paulus, T. J. Schmidt, H. A. Gaisteiger, R. J. Behm, J. Electroanal. Chem. 495 (2001) 134-145.

[7] F. Maillard, M. Martin, F. Gloaguen, J.M. Leger, Electrochim. Acta 47 (2002) 3431-3440.

[8] R. Benitez, A. M. Chaparro, L. Daza, J. Power Sources 151 (2005) 2-10.

[9] N.M.Markovic, H.A.Gasteiger, P.N.Ross, J. Phys. Chem.100 (1996) 6715-6721.

[10] K. J. J. Mayrhofer, D. Strmcnik, B. B. Blizanac, V. Stamenkovic, M. Arenz, N. M. Markovic, Electrochim. Acta 53 (2008) 3181-3188.

[11] C.A. Reiser, L. Bregoli, T.W. Patterson, J.S. Yi, J.D. Yang, M.L. Perry, T.D. Jarvi, Electrochemical and Solid State Letters 8 (2005) A273-A276.

[12] Y. Shao, G. Yin, Y. Gao, J. Power Sources 171 (2007) 558-566.

[13] J. Shim, C. R. Lee, H. K. Lee, J. S. Lee, E. J. Cairns, J. Power Sources, 102 (2001) 172-177.

[14] G. Chen, S. R. Bare, T. E. Mallouk, Journal of the Electrochemical Society, 149 (2002) A1092-A1099.

[15]S. Trasatti, Electrochimica Acta, 36, (1991) 225-241.

[16]B. Borresen, G. Hagen, R. Tunold, Electrochimica Acta, 47, (2002) 1819-1827.

[17]J. Aromaa, O. Forsen, Electrochimica Acta, 51, (2006) 6104-6110.

[18] J.P. Zheng and T.R. Jow, J. Electrochemical Society, 142, (1995) L6-L8. 
[19] O. E. Haas, S. T. Briskeby, O. E. Kongstein, M. Tsypkin, R. Tunold and B.T. Barresen, J. New Materials for Electrochemical Systems, 11(2008)9-14.

[20] Chih-Ping Lo, Guanxiong Wang, Amod Kumar, Vijay Ramani, Applied Catalysis

Environmental B: 140-141(2013)133-140.

[21] C.Chauvin, T. Saida, W. Sugimoto, J. Electrochemical Society, 161(2014) F318-F322.

[22] R. Srivastava, P. Strasser, ECS Transactions, 25(1), (2009) 565-571.

[23] S. Boujday, F. Wunsch, P. Portes, J. F. Bocquet, C. Colbeau-Justin, Solar Energy Materials \& Solar Cells 83 (2004) 421-433.

[24] K.W.Park, K.S.Seul, Electrochem. Communications, 9 (2007) 2256-2260.

[25] B.M. Babic, Lj.M. Vracar, V. Radmilovic, N.V. Krstajic, Electrochimica Acta 51, (2006) 3820-3826.

[26] K. Thamaphat, P. Limsuwan, B. Ngotawornchai, Kasetsart J. (Nat. Sci.) 42, (2008) 357361.

[27] J. F. Moulder, W. F. Stickle, P. E. Sobol, K. D. Bomben, "Handbook of X-Ray Photoelectron Spectroscopy", Physical Electronics Inc., Eden Prairie, Minnesota, USA, (1995). [28] Q. S. Chena, J. Solla-Gullóna, S.G. Sunb, J. M. Feliu, Electrochimica Acta 55 (2010) 7982 7994.

[29] A. Damjanovic, V. Brusic, Electrochim. Acta 12 (1967) 615-628.

[30] A. Damjanovic, M. Genshaw, Electrochim. Acta 15 (1970) 1281-1283.

[31] N.R. Elezovic, B.M. Babic, P. Ercius, V.R. Radmilovic, Lj.M. Vracar, N.V. Krstajic, Applied Catalysis B: Environmental 125, (2012) 390-397.

[32] R. G. Gonzalez-Huerta, J. A. Chavez-Carvayar, O. Solorza-Feria, Journal of Power Sources 153(2006)11-17

[33] M. Bron, P. Bogdanoff, S.Fiechter, M. Hilgendorff, J. Radnik, I. Dorbandt, H. Schulenburg, H. Tributsch, Journal of the Electroanalytical Chemistry 517(2001)85-94. 
[34] M. Hilgendorff, K. Diesner, H. Schulenurg, P. Bigdanoff, M. Bron, S. Fiecher, Journal of New Materials for Electrochemical Systems 5(2002)71-81.

[35] A. Altamirano-Gutierrez, O. Jimenez-Sandoval, J. Uribe-Godinez, R. H. Castellanos, E. Borja-Arco, J. M. Olivares-Ramirez, International Journal of Hydrogen Energy 34(2009)79837994.

[36] M. M. Jaksic, Electrochimica Acta, 45, (2000) 4085-4099.

[37] Lj. Vracar, N. V. Krstajic, V. R. Radmilovic, M. M. Jaksic, Journal of Electroanalytical Chemistry, 587, (2006) 99-107.

[38] K. E. Swider, C. I. Merzbacher, P. L. Hagans, D. R. Rolison, Chem. Mater., 9, (1997) 12481255. 


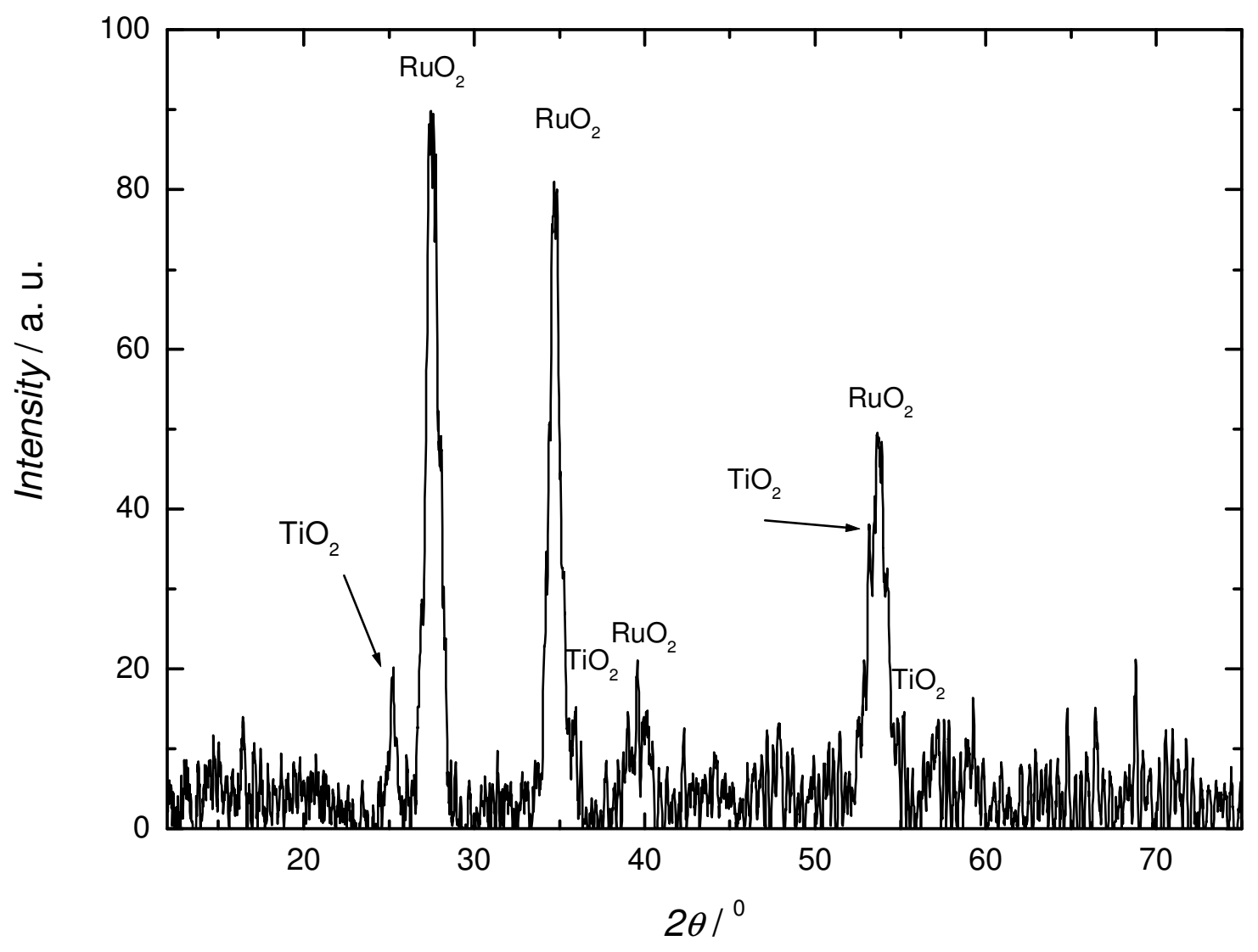

Fig.1 


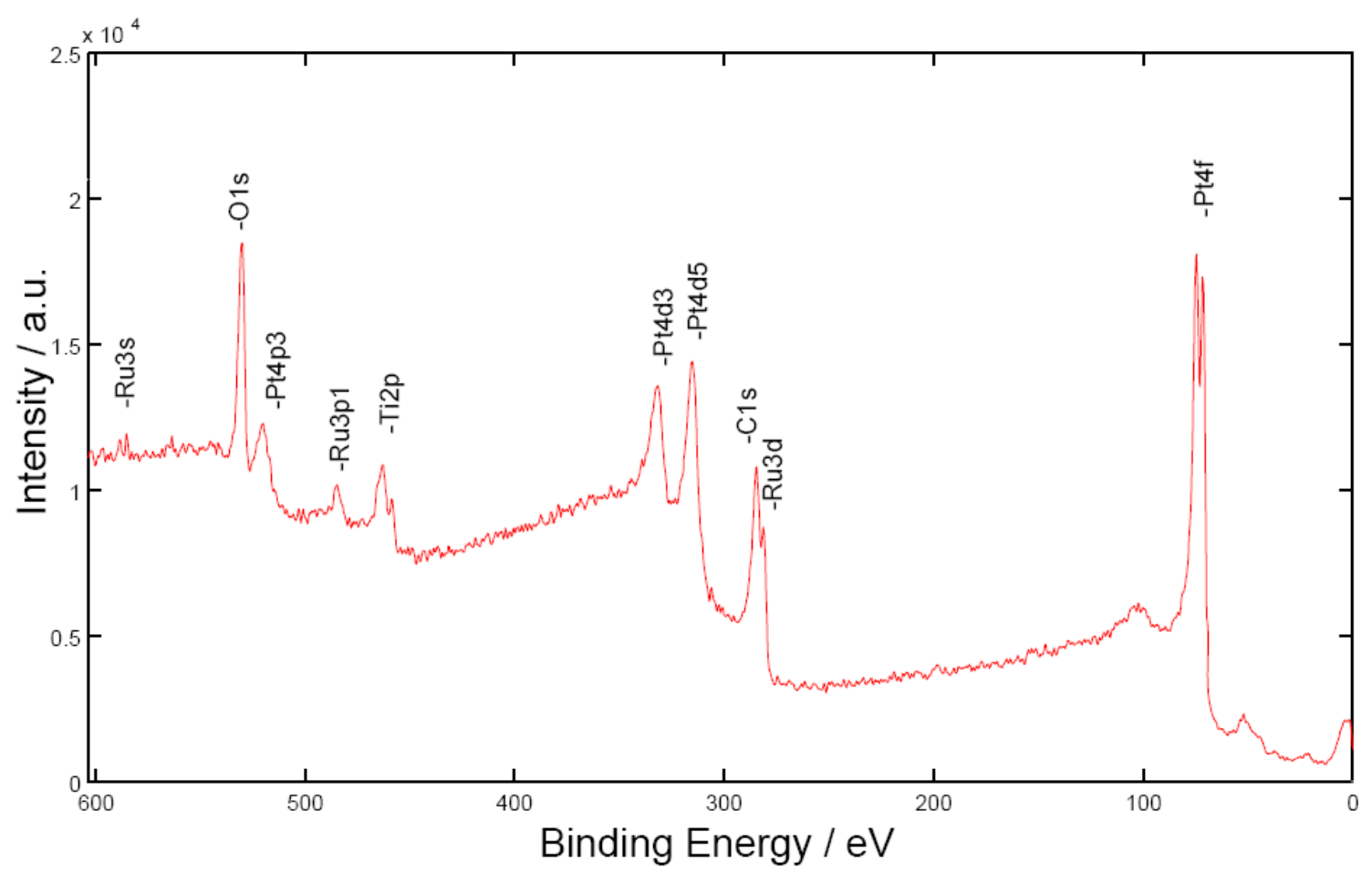

Fig.2 


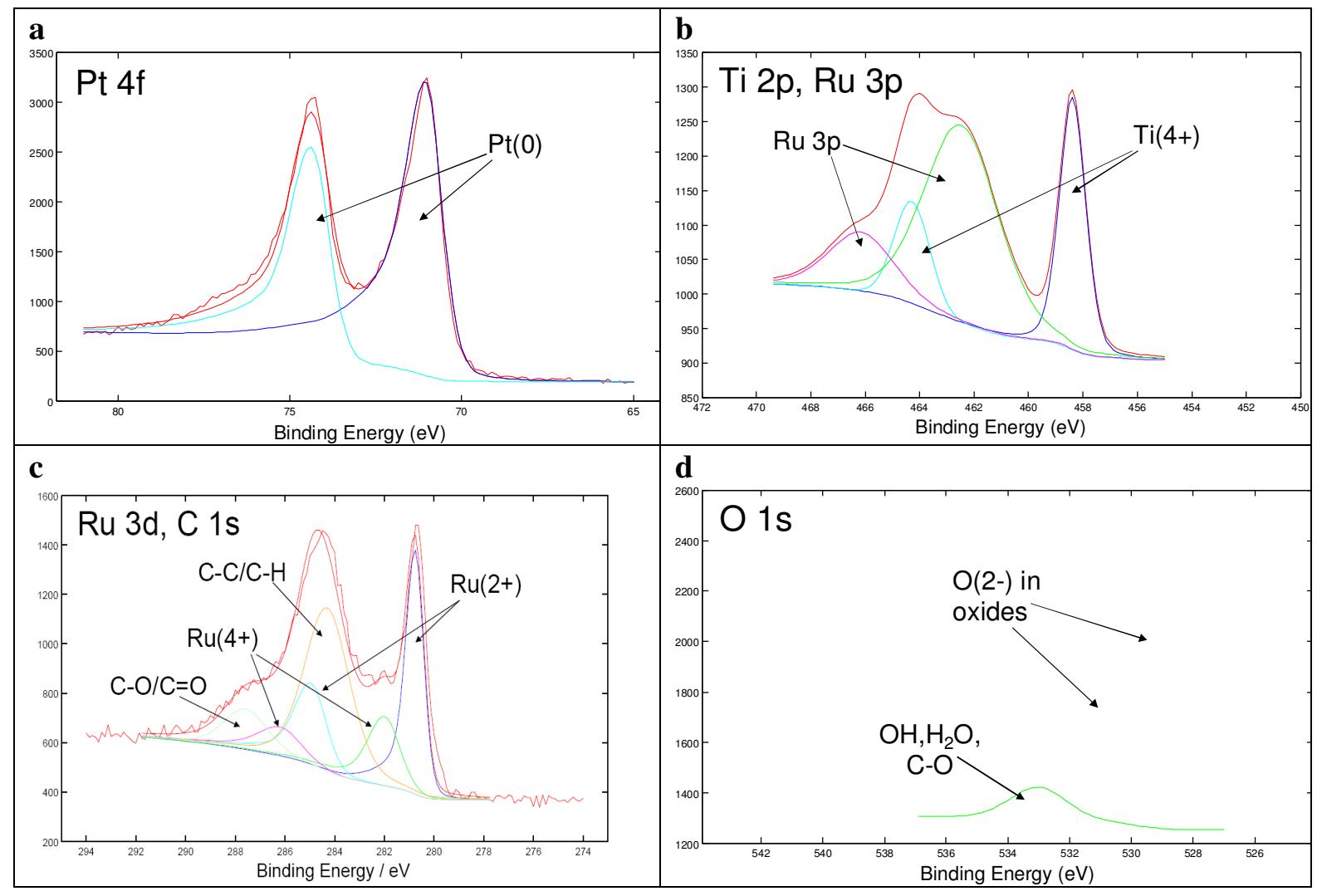

Fig.3 


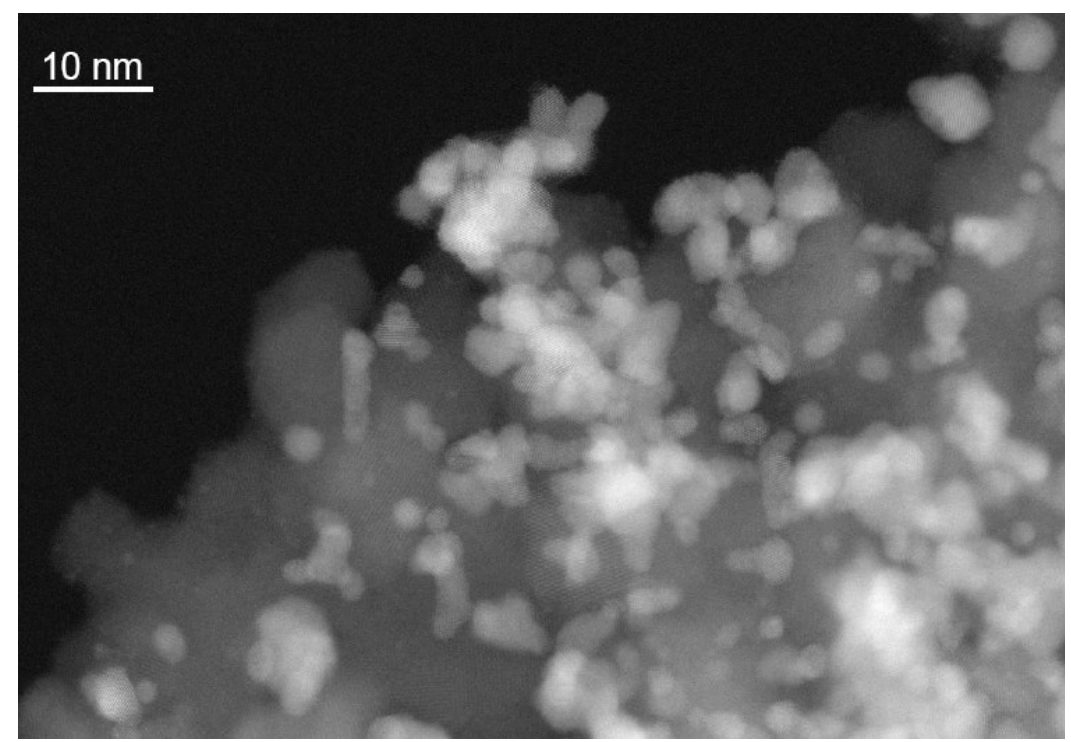

a)

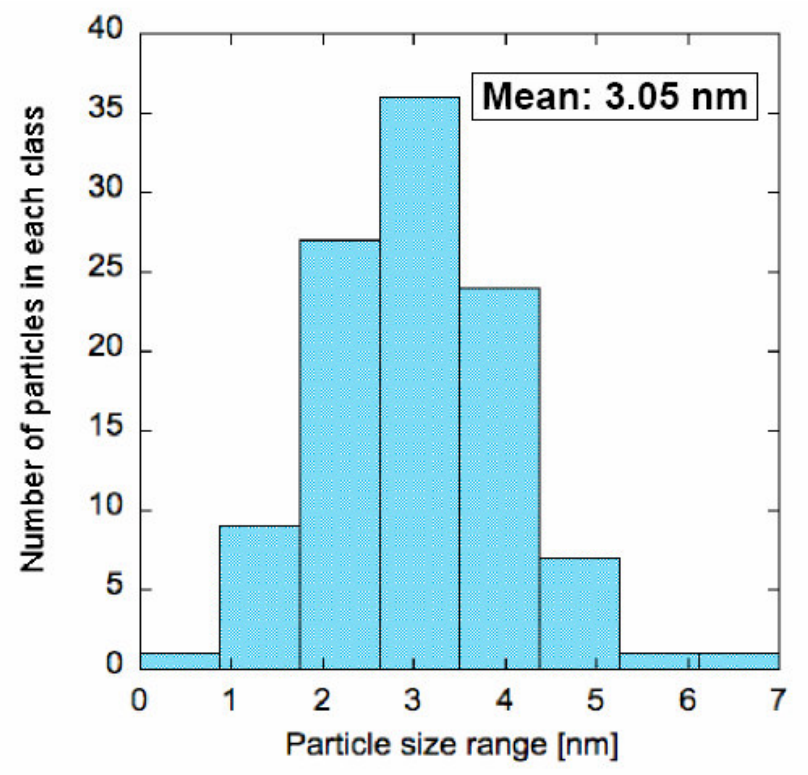

b)

Fig. 4 


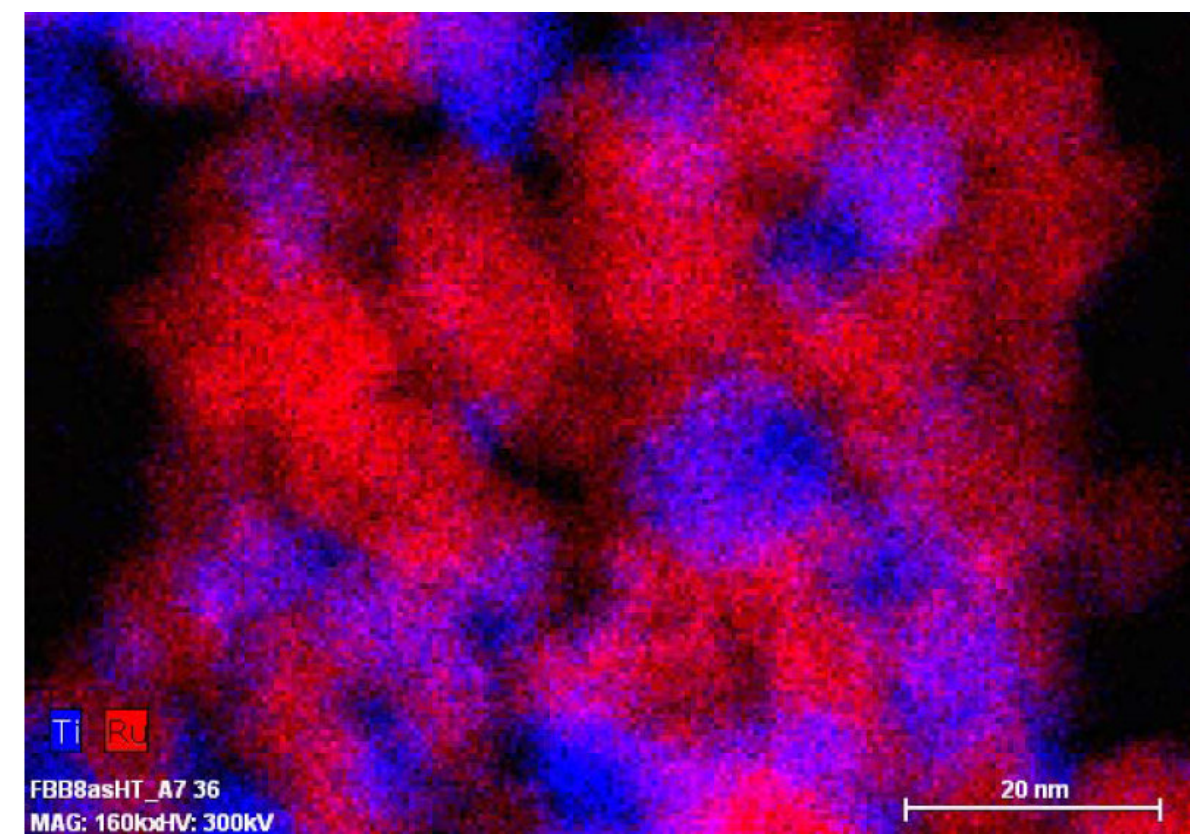

Fig.5 

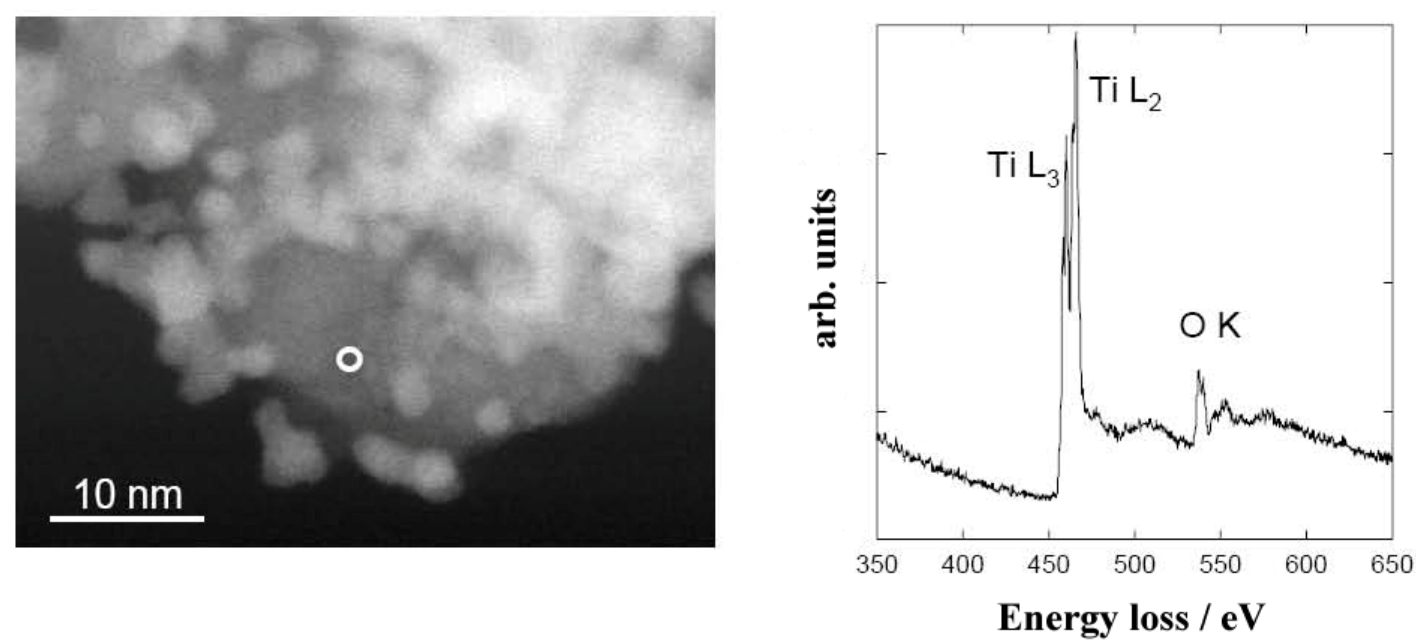

Fig.6a 

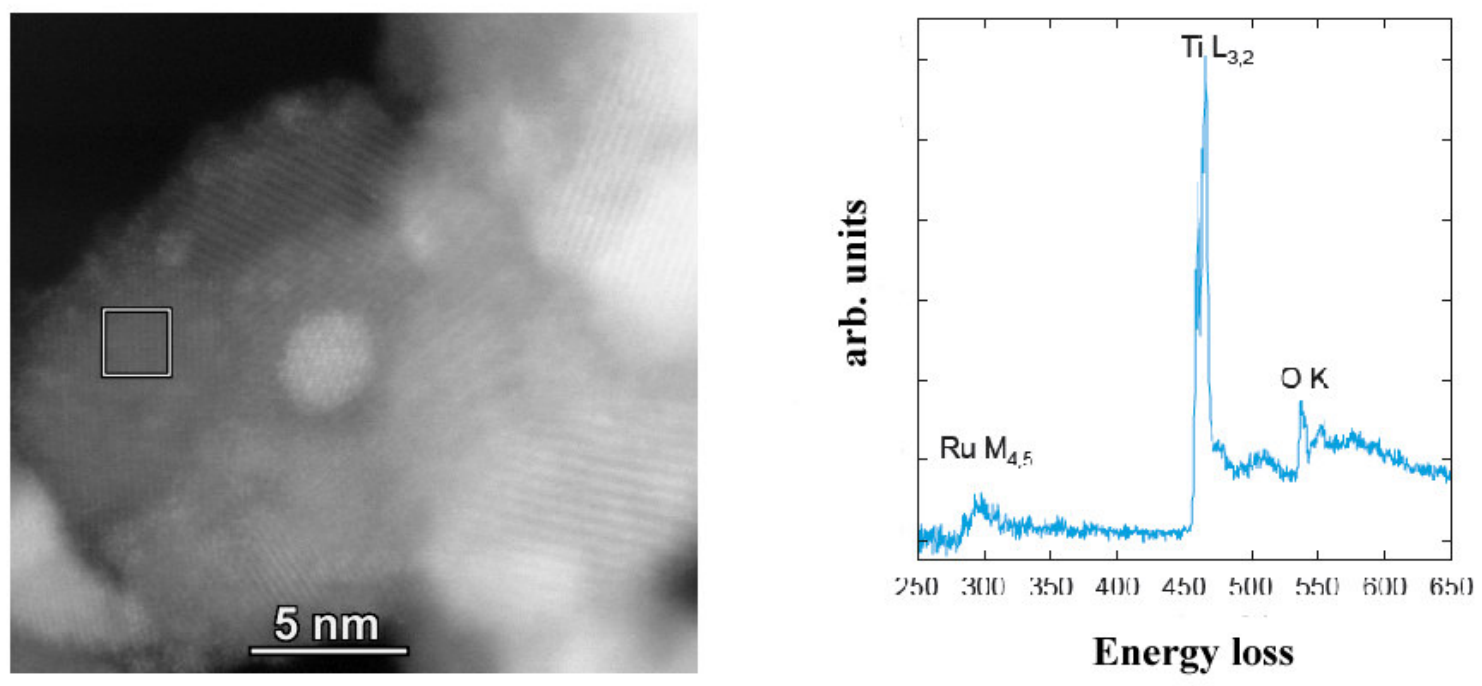

Fig.6b 


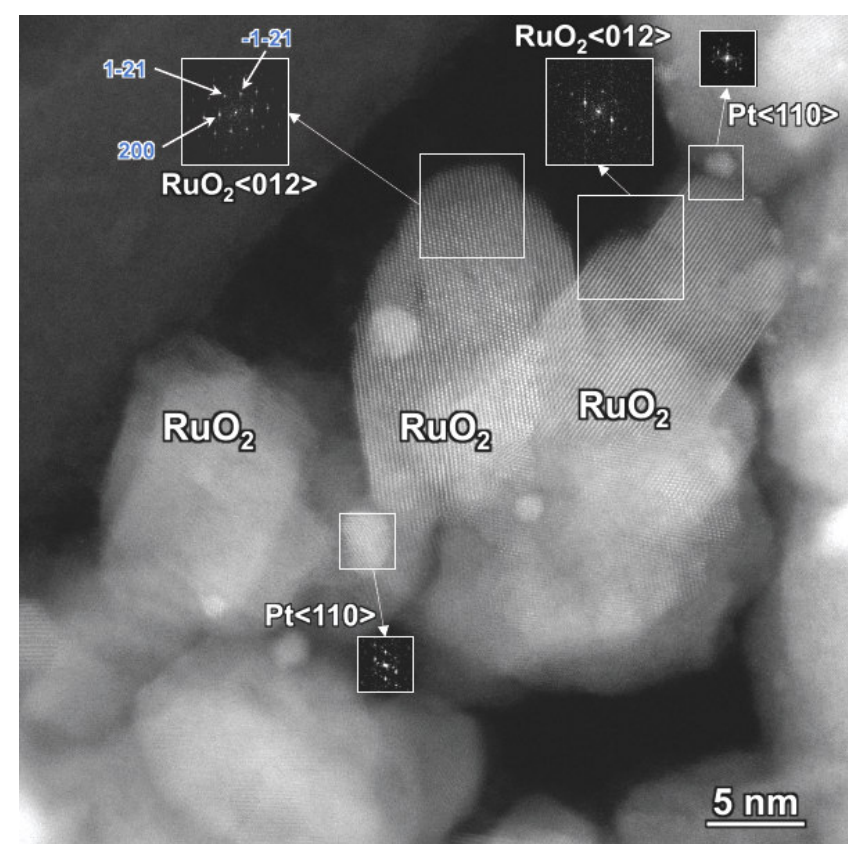

Fig.7a 


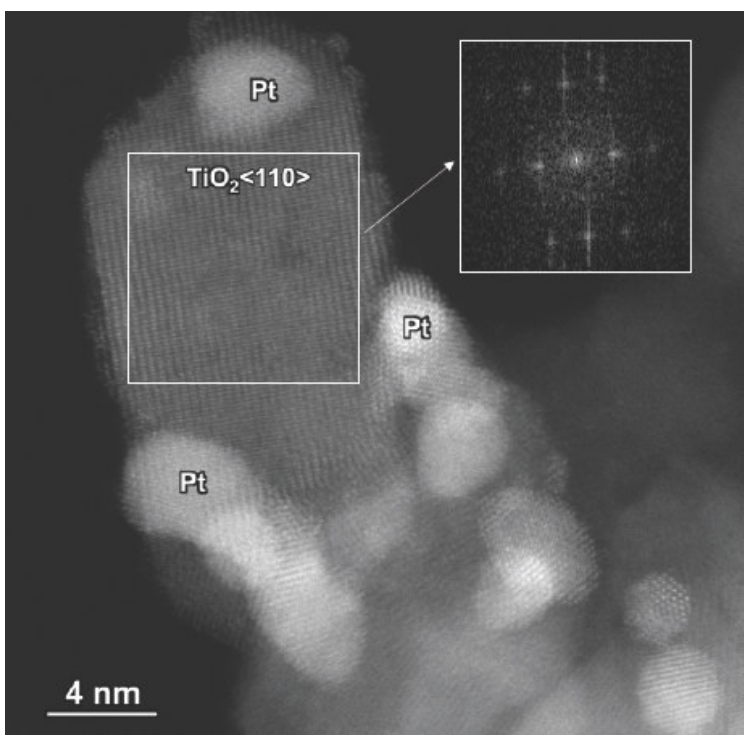

Fig. 7b 


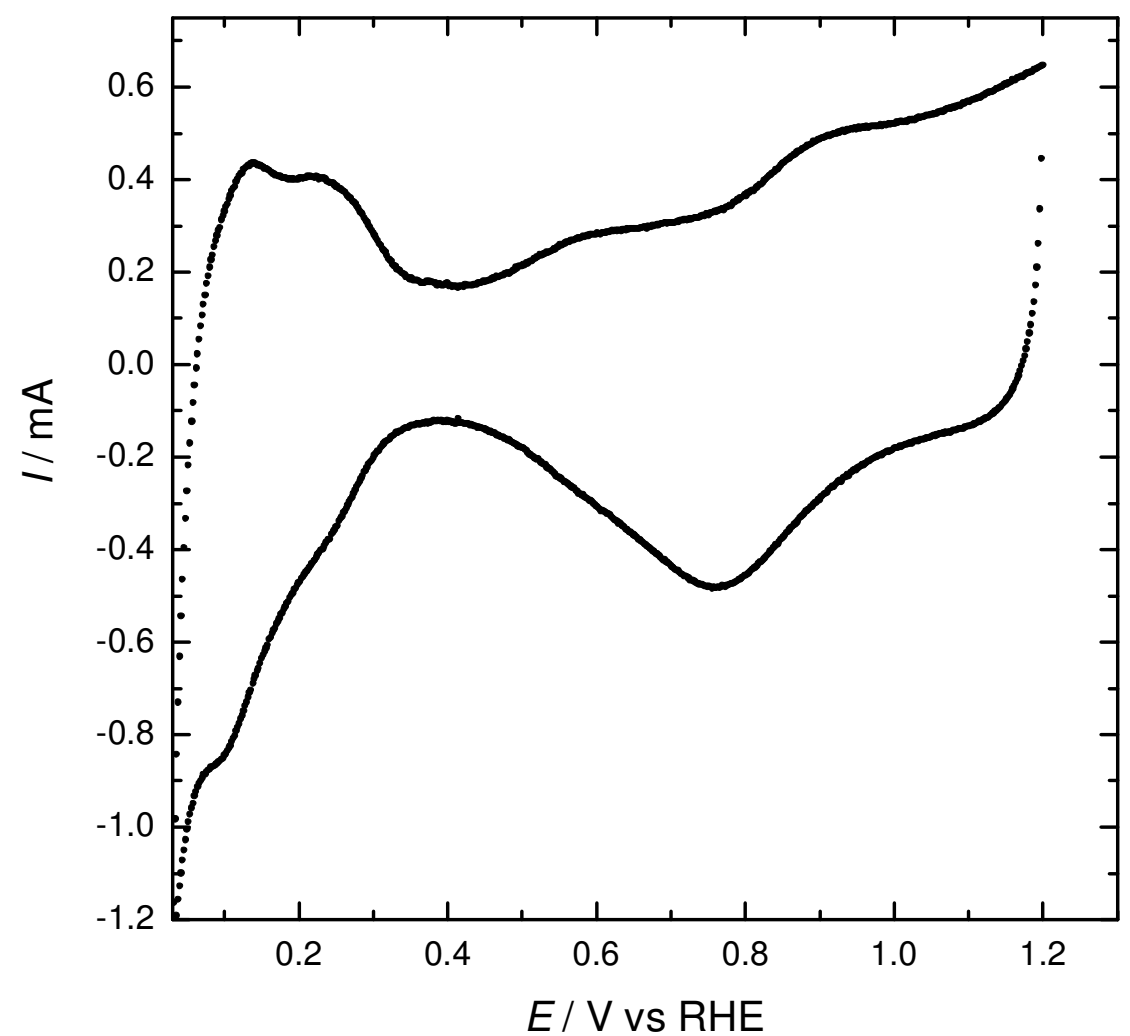

Fig.8 


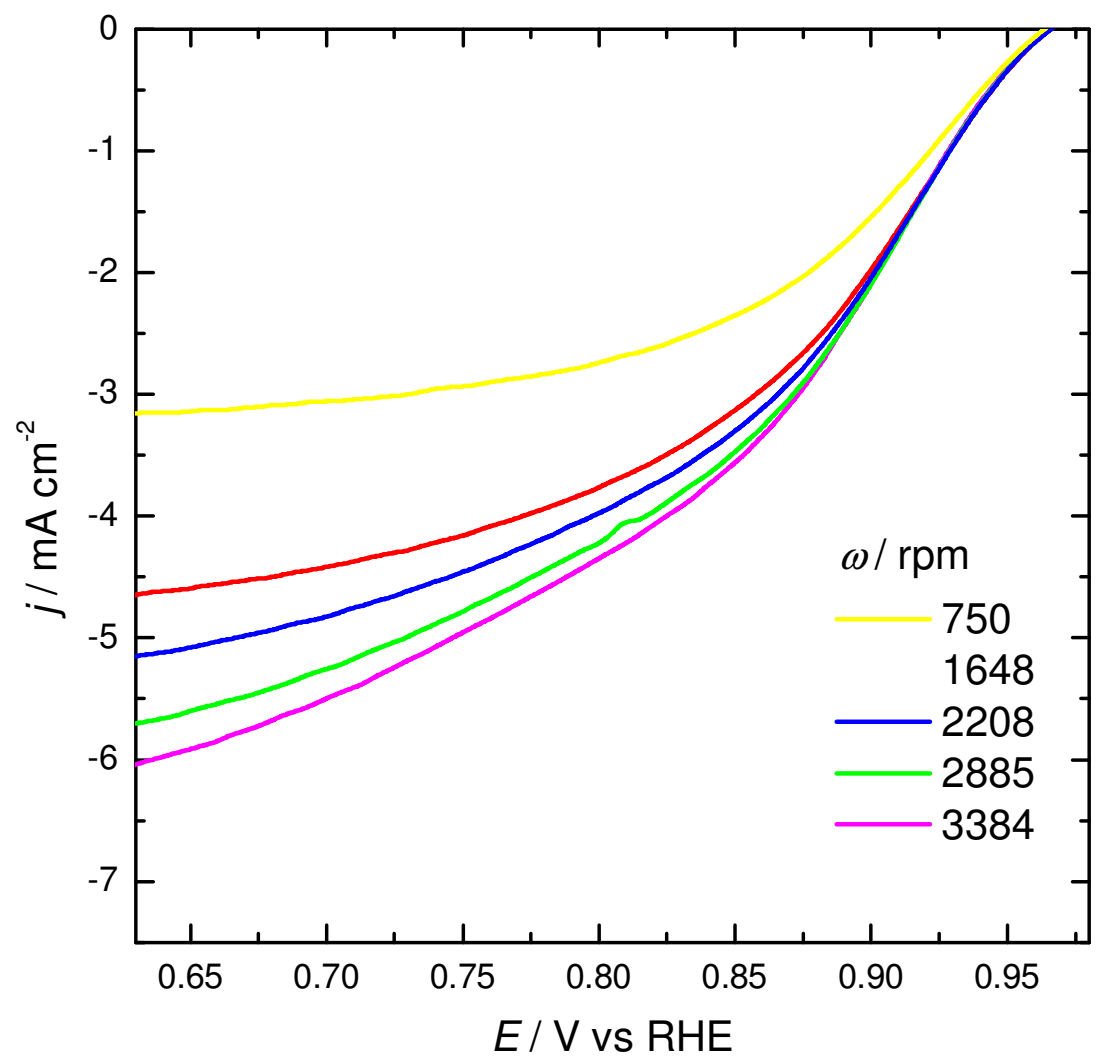

Fig.9 


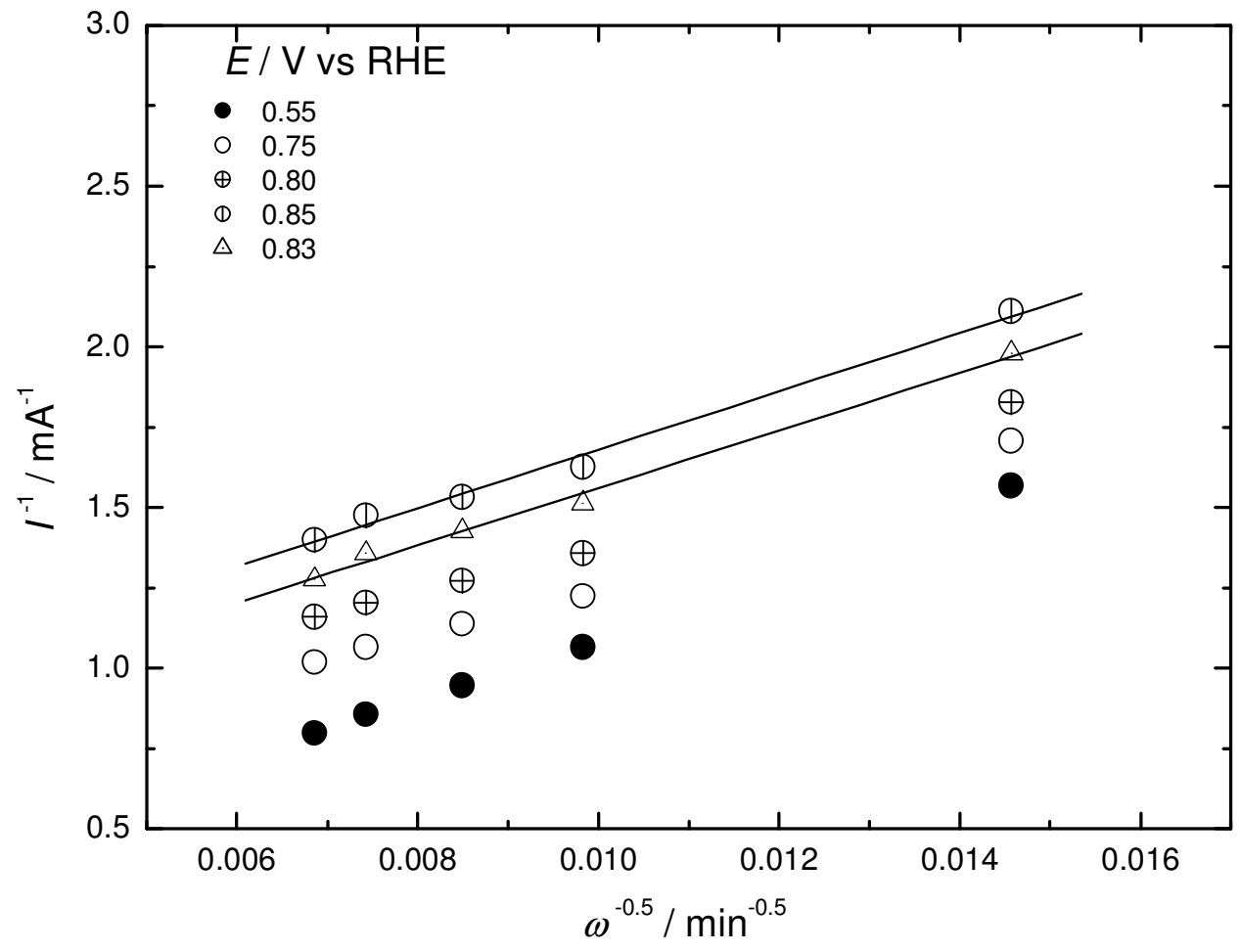

Fig.10 


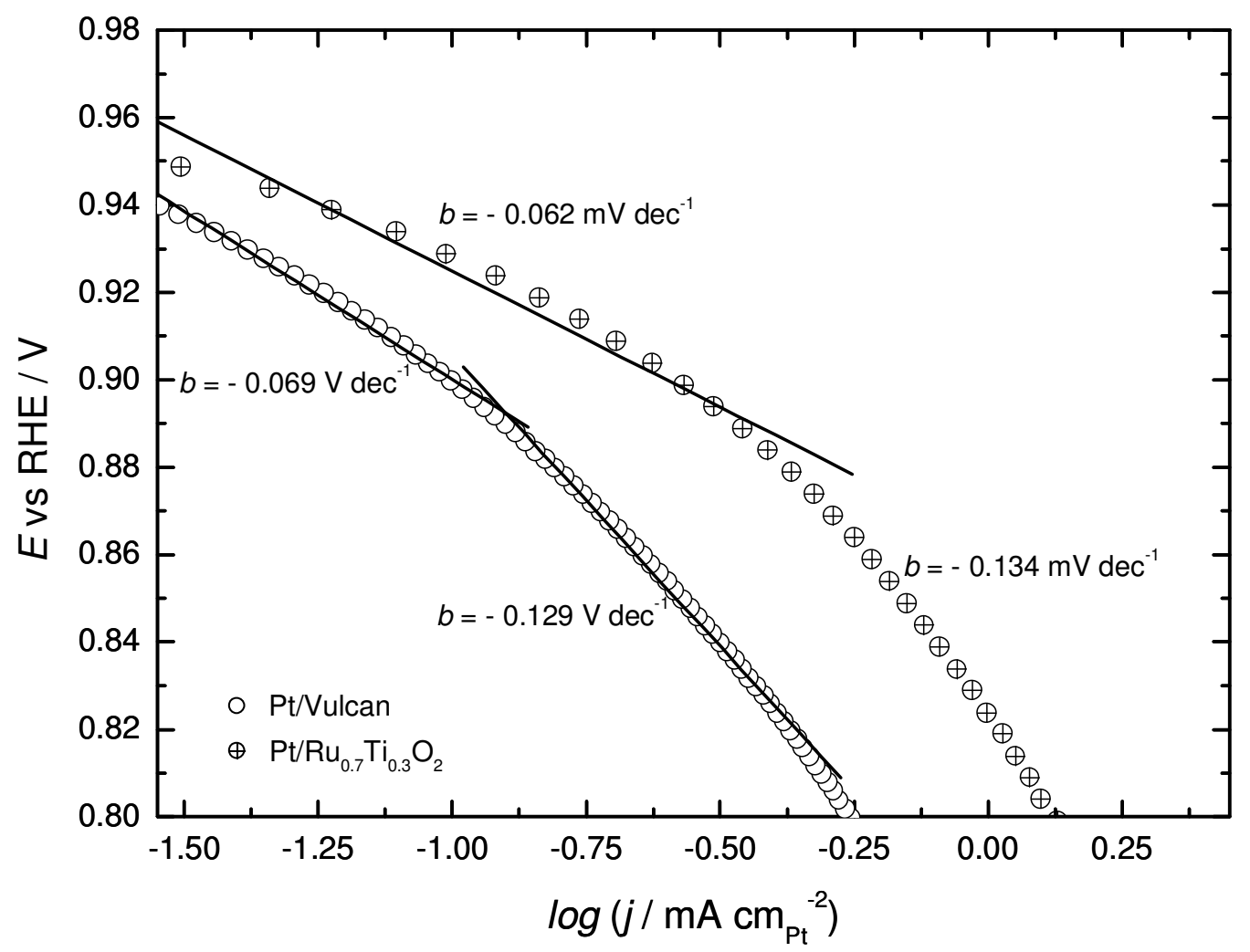

Fig.11 
Table 1

\begin{tabular}{lllclc}
\hline & $\begin{array}{l}\text { Electrochem. active } \\
\text { surface area } \\
\text { Catalyst }\end{array}$ & \multicolumn{2}{c}{$\begin{array}{l}\text { Mass activity } \\
(\mathrm{mA} / \mathrm{mg} \mathrm{Pt})\end{array}$} & \multicolumn{2}{l}{$\begin{array}{l}\text { Specific activity } \\
\left(\mu \mathrm{A} / \mathrm{cm}^{2} \mathrm{Pt}\right)\end{array}$} \\
& & 0.85 & 0.90 & 0.85 & 0.90 \\
\hline $\mathrm{Pt} / \mathrm{C}$ & 92 & 243 & 94 & 265 & 102 \\
\hline $\mathrm{Pt} / \mathrm{Ru}_{0.7} \mathrm{Ti}_{0.3} \mathrm{O}_{2}$ & 32 & 218 & 85 & 680 & 265 \\
\hline
\end{tabular}

